\title{
Serum Immunoglobulin and Transferrin Levels After Childhood Splenectomy
}

\author{
M. J. SCHUMACHER \\ From the Surgical Research Department, Royal Children's Hospital Research Foundation, \\ Melbourne, Australia
}

\begin{abstract}
Schumacher, M. J. (1970). Archives of Disease in Childhood, 45, 114 . Serum immunoglobulin and transferrin levels after childhood splenectomy. IgG, IgA, IgM, and transferrin levels were measured in sera from a group of children who had been subjected to splenectomy in the previous 10 years. In those children splenectomized for hereditary spherocytosis, idiopathic thrombocytopenic purpura, or traumatic rupture, mean IgM levels were significantly lower and mean transferrin levels were significantly higher than in sera from control children.

Children splenectomized for thalassaemia major had a significantly raised mean IgG level, while children splenectomized for portal hypertension had a raised mean IgA level. However, IgG and IgA levels in patients who had suffered splenic rupture did not differ from control values.

The finding of high transferrin levels after splenectomy supports the concept of an immunological function for this protein in addition to its iron-binding capacity.
\end{abstract}

Since the first report of the increased incidence of serious infection in children following splenectomy (King and Shumacker, 1952), a number of studies showing a similarly high incidence of infection after this operation in early childhood have been published. These reports, reviewed critically and supplemented by Horan and Colebatch (1962) and by Erickson, Burgert, and Lynn (1968), show that meningitis and septicaemia occur in $5-8 \%$ of subjects, and when they do occur, the mortality is high.

This increased risk may be explained in terms of the known ability of the spleen to clear particulate matter from the blood-stream. For instance, there is some evidence to suggest that uptake of particulate antigen from the blood-stream in man is more efficient in the spleen than in the liver when levels of specific antibody are low (Jandl and Kaplan, 1960).

Though the spleen is known to be capable of specific antibody synthesis, the effect of splenectomy on total antibody production in children has been the subject of conflicting reports: some workers (Rowley, 1950; Huang, Sheng, and Pilling, 1960)

Received 5 May 1969.

*Present address: University of Colorado Medical Center, 4200 East Ninth Avenue, Denver, Colorado 80220, U.S.A. were able to show impairment of antibody respoisses after removal of the spleen, but others (Smith esap 1957; Saslaw et al., 1959; Doan, Bouroncle an Wiseman, 1960; Thurman, 1963) were not able show such impairment of response in asplen individuals.

Immunochemical estimation of total serum immunoglobulin concentrations has not been studied extensively, since it has been shown repeatedly that total $\gamma$-globulin levels in splenectomized children are normal. However, Scheidegger and Martin du Pan (1957) showed absence of IgA and IgM arcs on immunoelectrophoresis of serum from 2 splenectomized infants, and Broberger, Gyulä, and Hirschfeldt (1960) reported IgA deficien $y^{2}$ in 12 of 28 splenectomized children. This study was undertaken in order to amplify these immungelectrophoretic findings.

\section{Patients and Methods}

At the Royal Children's Hospital, Melbourne, 142 children had been subjected to splenectomy in the past 10 years. Venous blood was obtained from each of the 80 children who were available for study. The ages at splenectomy ranged from 3 days to 16 years, and at the time of blood collection their ages ranged from $\$ 5$ months to 22 years.

Splenectomy was performed for splenic rupture, 
hereditary spherocytosis, thrombocytopenic purpura, hypersplenism associated with thalassaemia major, or to facilitate shunting procedures in portal hypertension. Serum samples from 10 children were obtained both before and after splenectomy.

Control serum samples were obtained from 67 children with traumatic injuries other than splenic rupture or who were undergoing cardiac catheterization for congenital heart disease. As these children were otherwise healthy, it was assumed that their immunoglobulin levels would lie in the normal range. In addition, samples were obtained from 20 blood donors aged between 18 and 22 years.

All sera were stored in small aliquots at $-20^{\circ} \mathrm{C}$. until assayed. Immunoelectrophoresis was performed in agar gel using horse antihuman polyvalent antiserum (Hyland Laboratories). Each test serum was run with a normal control serum and was studied undiluted and diluted $1: 2$ and $1: 4$. Estimation of immunoglobulin and transferrin levels was performed by radial immunodiffusion in antibody agar plates (Immunoplates, Hyland Laboratories), using 3 standard sera in each plate. The limits of error in this method were $8 \%$. Where protein levels in the test serum were well outside the range of the standard protein levels, appropriate dilutions were performed to bring the test protein concentration inside the limits of the standard protein concentration. If the protein concentration of a test sample was not consistent with the appearance of the corresponding arc on immunoelectrophoresis, the radial immunodiffusion assay was repeated.

As a number of previous studies of normal children (e.g. Stiehm and Fudenberg, 1966) have shown, control IgG and IgA levels rose with age, reaching adult levels by 5 years, and IgM levels increased progressively until 2 years of age. Transferrin levels did not change with age, and therefore means for all patients irrespective of age were calculated. Lack of significant age variation in control patients beyond 5 years for $\mathrm{IgG}$ and IgA and beyond 2 years for IgM enabled calculation of mean values for all splenectomized children over these ages and their consideration as a single population for comparison with the corresponding control group. The two groups were not comparable in number under 3 years, but there was an approximately equivalent age distribution beyond this age. It was considered that any inequality in age distribution was irrelevant if the age-group under consideration had reached a constant adult level.

Analysis of variation and covariation was applied to all $\operatorname{IgG}, \operatorname{IgA}, \operatorname{IgM}$, and transferrin levels to ensure the validity of closer examination within individual disease groups. This requirement was met for all 4 proteins. Where statistical treatment of the data was possible, means and standard deviations were calculated and compared with those of the control values. Standard deviations were compared using the variance ratio test and if found to be similar, the significance of difference between the means was estimated using the Student's t test. Where the standard deviations differed significantly, analysis of variation and covariation was applied in order to compare test and control protein levels.

Results from one patient were excluded from the statistical calculations, since his spleen was removed during the course of a generalized reticuloendothelial disorder which may have represented a primary immunological disease. The findings in this patient, which included absence of isohaemagglutinins and IgM deficiency, have been reported in detail elsewhere (Schumacher, Dennett, and Wettenhall, 1967).

\section{Results}

In order to exclude the influence of underlying disease on immunoglobulin levels and to estimate the effect of splenectomy alone, data obtained from children who had undergone splenectomy for splenic rupture were compared with control values. These 2 groups showed no difference with respect to mean IgG and IgA levels, but in the rupture group the mean IgM level was significantly lower and the mean transferrin level was significantly higher than the corresponding values in the control group (Table). Children splenectomized for hereditary spherocytosis and idiopathic thrombocytopenic purpura showed similar differences from control values.

The influence of disease alone on immunoglobulin levels was assessed by comparison of children splenectomized for a medical disease and children splenectomized for rupture. Children with thalassaemia major had significantly higher IgG levels than did the patients in the trauma group. Thalassaemia major was the only underlying disease associated with normal mean transferrin levels. Children with portal venous obstruction had significantly higher IgA levels than did control patients, but the mean IgA level was also significantly higher than that of rupture patients, suggesting that portal hypertension per se had led to increase in IgA levels.

Immunoglobulin and transferrin levels were performed before and after operation in 10 cases. IgG, IgM, and transferrin levels did not show a consistent change after operation but there was an early tendency to an increase in IgA (Fig.).

Only 2 of the children in the survey were known to have suffered serious infection. One of them, a 13-year-old girl with thalassaemia major, died suddenly 3 months after the sample was taken. Her serum immunoglobulin levels were raised (IgG, $2800 \mathrm{mg} . / 100 \mathrm{ml}$; IgA, $280 \mathrm{mg} . / 100 \mathrm{ml}$; IgM, $315 \mathrm{mg} . / 100 \mathrm{ml}$.). This child, who had undergone splenectomy at the age of 15 months, succumbed to a brief febrile illness associated with urinary tract infection. Permission for necropsy was refused. Another child, splenectomized at 
TABLE

Immunoglobulin and Transferrin Levels

\begin{tabular}{|c|c|c|c|c|c|c|c|}
\hline & & Rupture & $\begin{array}{l}\text { Hereditary } \\
\text { Spherocytosis }\end{array}$ & $\begin{array}{l}\text { Idiopathic } \\
\text { Thrombo- } \\
\text { cytopenic } \\
\text { Purpura }\end{array}$ & $\begin{array}{c}\text { Thalassaemia } \\
\text { Major }\end{array}$ & $\begin{array}{c}\text { Portal } \\
\text { Hypertension }\end{array}$ & Controls \\
\hline $\begin{array}{l}\text { IgG } \\
\text { (beyond age } \\
5 \text { yr.) }\end{array}$ & 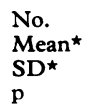 & $\begin{array}{r}27 \\
1218 \\
246 \\
\mathrm{NS}\end{array}$ & $\begin{array}{r}14 \\
1203 \\
237 \\
\text { NS }\end{array}$ & $\begin{array}{c}8 \\
993 \cdot 7 \\
36.3 \\
\text { NS }\end{array}$ & $\begin{array}{c}9 \\
1949 \\
658 \\
<0.001\end{array}$ & $\begin{array}{r}9 \\
1425 \\
588 \\
\text { NS }\end{array}$ & 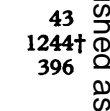 \\
\hline $\begin{array}{l}\text { IgA } \\
\text { (beyond age } \\
5 \text { yr.) }\end{array}$ & $\begin{array}{l}\text { No. } \\
\text { Mean } \\
\text { SD } \\
\mathrm{p}\end{array}$ & $\begin{array}{r}27 \\
164 \cdot 9 \\
64 \cdot 9 \\
\text { NS }\end{array}$ & $\begin{array}{c}14 \\
224 \\
78 \cdot 0 \\
\text { NS }\end{array}$ & $\begin{array}{l}8 \\
191 \cdot 6 \\
165 \\
\text { NS }\end{array}$ & $\begin{array}{r}10 \\
239 \\
97 \cdot 5 \\
\text { NS }\end{array}$ & $\begin{array}{c}9 \\
276 \cdot 7 \\
152 \\
0 \cdot 01\end{array}$ & $\begin{array}{r}43 \\
183 \cdot 3 \\
80 \cdot 1\end{array}$ \\
\hline $\begin{array}{l}\text { IgM } \\
\text { (beyond age } \\
2 \text { yr.) }\end{array}$ & $\begin{array}{l}\text { No. } \\
\text { Mean } \\
\text { SD } \\
\mathrm{p}\end{array}$ & $\begin{array}{l}31 \\
58 \cdot 7 \\
31 \cdot 0 \\
<0 \cdot 001\end{array}$ & $\begin{array}{l}15 \\
64 \cdot 1 \\
29 \cdot 2 \\
<0 \cdot 05\end{array}$ & $\begin{array}{c}9 \\
56 \cdot 9 \\
21 \cdot 8 \\
<0.05\end{array}$ & $\begin{array}{l}12 \\
97 \cdot 5 \\
86 \cdot 8 \\
\text { NS }\end{array}$ & $\begin{array}{l}9 \\
79 \cdot 6 \\
27 \cdot 9 \\
\text { NS }\end{array}$ & $\begin{array}{l}66 \text { ? } \\
93 \cdot 4 \text { ? } \\
46 \cdot 8 \text { ? }\end{array}$ \\
\hline $\begin{array}{l}\text { Transferrin } \\
\text { (all ages) }\end{array}$ & $\begin{array}{l}\text { No. } \\
\text { Mean } \\
\text { SD } \\
\text { p }\end{array}$ & $\begin{array}{l}30 \\
275 \cdot 7 \\
102 \cdot 2 \\
<0 \cdot 001\end{array}$ & $\begin{array}{l}14 \\
255 \\
70 \cdot 2 \\
0 \cdot 05\end{array}$ & $\begin{array}{c}9 \\
281 \cdot 6 \\
53 \cdot 7 \\
0 \cdot 01\end{array}$ & $\begin{array}{c}11 \\
186 \cdot 4 \\
57 \cdot 3 \\
\text { NS }\end{array}$ & $\begin{array}{c}9 \\
259 \cdot 2 \\
113 \\
\text { NS }\end{array}$ & $\begin{array}{r}84 \\
212 \cdot 6 \\
75 \cdot 9\end{array}$ \\
\hline
\end{tabular}

${ }^{\star}$ mg. per $100 \mathrm{ml}$.

tdistribution in this group positively skewed (median $=1100$ )

SD = standard deviation

$p=$ level of significance of difference from control values.

NS $=$ no significant difference from control values.

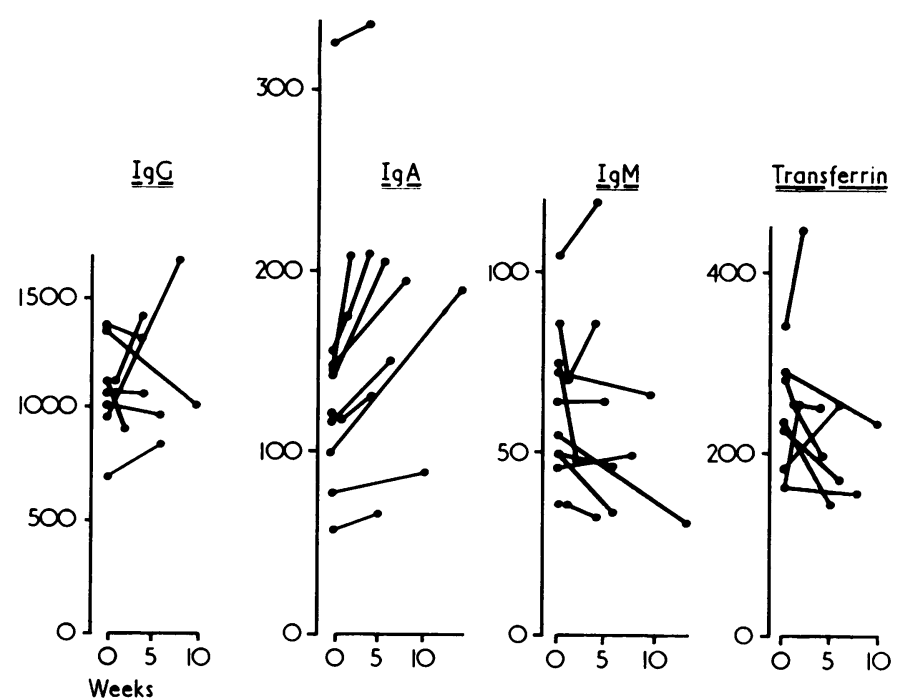

Fig.-Change in protein levels (mg./100 ml.) with time (weeks after splenectomy).

8 months for hereditary spherocytosis, suffered Haemophilus influenzae meningitis 11 months later, and recovered. Her immunoglobulin levels at the age of 9 years were not decreased (IgG, 1600 mg./100 ml.; IgA, $310 \mathrm{mg} . / 100 \mathrm{ml}$; IgM, 110 mg./100 ml.).

\section{Discussion}

The finding of low mean IgM levels and high mean transferrin levels in asplenic children cơnflicts with results obtained by Broberger et (1960) who, on visual inspection of the immunoelectrophoresis of 28 splenectomized childrege, found that in some sera the IgM arcs looked normal, but arcs of transferrin and IgA were weak or absent. However, at the time of that investigation it was nopt possible to check these findings by immung- 
chemical measurement of IgA and IgM levels, and only 3 transferrin levels were confirmed by quantitation.

The low mean serum IgM levels after splenectomy in children suggest that the spleen contributes relatively more IgM than IgG and IgA to the total serum immunoglobulin content. The alternative explanation, namely that the spleen normally stimulates IgM production by other lymphoid tissues, lacks information in its support.

Despite the small difference between IgM levels of splenectomy patients and controls found in this survey, it is possible that some patients may have suffered a considerable fall in IgM levels after operation. Since IgM plays an important role in opsonization and in the initial antibody response to new antigens, this group may have become susceptible to overwhelming infection by virtue of deficiency of opsonizing antibody and of deficient primary antibody responses. This is supported by evidence that asplenic rabbits have lost their ability for rapid synthesis of opsonizing antibody (Ellis and Smith, 1966). Similarly, splenectomized calves are slow to produce $\operatorname{IgM}$ in response to infection with Anaplasma marginale (Klaus and Jones, 1968). In addition, patients with isolated IgM deficiency associated with bacterial meningitis have been described (Schumacher et al., 1967; Hobbs, Milner, and Watt, 1967).

The raised mean transferrin levels in splenectomized children may reflect the effect of altered erythrokinetics on iron metabolism. However, an increase of serum transferrin may be part of a non-specific response to infection in the absence of splenic function. This view is supported by evidence for the antibacterial effect of human transferrin in mice (Martin, Jandl, and Finland, 1963). Moreover, it has been shown that children with congenital a- $\gamma$-globulinaemia may have raised concentrations of serum transferrin associated with increased levels of heat-stable bacteriostatic activity (Martin, 1962). The apparent paradox of normal transferrin levels in splenectomized thalassaemic children may be explained by the reported tendency to reduction of serum transferrin in thalassaemia (Dettori et al., 1966).

The present largely retrospective survey has shown differences between test and control patients which require confirmation by results of a prospective study. This study has been started, but because only a few of the splenectomized patients in the retrospective survey had very low IgM levels, a large number of children will need to be studied before operation and for a prolonged period after operation.
This work was supported by grants from the Royal Children's Hospital Research Foundation, and from the Felton Bequest. I am indebted to Mr. Robert Fowler for his guidance during this survey, and to Ian Goller for technical advice. I thank Dr. Alan Williams for use of the facilities of the Pathology Department, and the Senior Medical Staff of the Royal Children's Hospital, Melbourne, for access to their patients.

\section{REFERENCES}

Broberger, O., Gyulai, F., and Hirschfeldt, J. (1960). Splenectomy in childhood. A clinical and immunological study of fortytwo children splenectomized in the years 1951-1958. Acta Paediatrica, 49, 679.

Dettori, M., Vierucci, A., Varone, D., and Borgatti, L. (1966). Studio immunoelettroforetico delle proteine plasmatiche di bambini affetti da malattia di Cooley. Rivista di Clinica Pediatrica, 77, 195.

Doan, C. A., Bouroncle, B. A., and Wiseman, B. K. (1960). Idiopathic and secondary thrombocytopenic purpura: clinical study and evaluation of 381 cases over a period of 28 years. Annals of Internal Medicine, 53, 861.

Ellis, E. F., and Smith, R. T. (1966). The role of the spleen in immunity: with special reference to the post-splenectomy problem in infants. Pediatrics, 37, 111.

Erickson, W. D., Burgert, E. O., Jr., and Lynn, H. B. (1968). The hazard of infection following splenectomy in children. American Fournal of Diseases of Children, 116, 1.

Hobbs, J. R., Milner, R. D. G., and Watt, P. J. (1967). Gamma-M deficiency predisposing to meningococcal septicaemia. British Medical fournal, 4, 583.

Horan, M., and Colebatch, J. H. (1962). Relation between splenectomy and subsequent infection. A clinical study. Archives of Disease in Childhood, 37, 398.

Huang, N. N., Sheng, K. T., and Pilling, G. P. (1960). Antibody response to $\mathrm{Vi}$ antigen administered subcutaneously and intravenously following splenectomy in children. (Abstr.) American fournal of Diseases of Children, 100, 699.

Jandl, J. H., and Kaplan, M. E. (1960). The destruction of red cells by antibodies in man. III. Quantitative factors influencing the patterns of hemolysis in vivo. fournal of Clinical Investigation, 39, 1145.

King, H., and Shumacker, H. B., Jr. (1952). Splenic studies. I. Susceptibility to infection after splenectomy performed in infancy. Annals of Surgery, 136, 239.

Klaus, G. G. B., and Jones, E. W. (1968). The immunoglobulin response in intact and splenectomized calves infected with Anaplasma marginale. Fournal of Immunology, 100, 991.

Martin, C. M. (1962). Relation of transferrin to serum bacteriostatic activity in agammaglobulinemic and other patients. American fournal of the Medical Sciences, 244, 334.

, Jandl, J. H., and Finland, M. (1963). Enhancement of acute bacterial infections in rats and mice by iron and their inhibition by human transferrin. Fournal of Infectious Diseases, 112, 158.

Rowley, D. A. (1950). The formation of circulating antibody in the splenectomized human being following intravenous injection of heterologous erythrocytes. Fournal of Immunology, 65, 515.

Saslaw, S., Bouroncle, B. A., Wall, R. L., and Doan, C. A. (1959). Studies on the antibody response in splenectomized persons. New England fournal of Medicine, 261, 120.

Scheidegger, J. J., and Martin du Pan, R. (1957). Étude immunoélectrophorétique des protéines sériques du nouveau-né et du nourrisson. Études Néo-natales, 6, 135.

Schumacher, M. J., Dennett, X., and Wettenhall, H. N. B. (1967). IgM deficiency with hypergammaglobulinaemia and recurrent mononucleosis. Australian Paediatric fournal, 3, 15.

Smith, C. H., Erlandson, M., Schulman, I., and Stern, G. (1957). Hazard of severe infections in splenectomized infants and children. American fournal of Medicine, 22, 390.

Stiehm, E. R., and Fudenberg, H. H. (1966). Serum levels of immune globulins in health and disease: a survey. Pediatrics, $37,715$.

Thurman, W. G. (1963). Splenectomy and immunity. American fournal of Diseases of Children, 105, 138. 